\title{
Effect of High Volume Hemodiafiltration on Secondary Hyperparathyroidism Among Hemodialysis Patients
}

\author{
Ezzat Abdalrahman El Etreby, Mohamed Said El-Shorbagy, Al-Sayed Mohamed Rashed, \\ Ahmed Mohamed Alsawy*
}

Department of Internal Medicine and Nephrology, Department of Clinical Pathology, Faculty of Medicine, Al Azhar University, Cairo, Egypt

Email address:

Ahmedelsawy2020@yahoo.com (A. M. Alsawy)

*Corresponding author

\section{To cite this article:}

Ezzat Abdalrahman El Etreby, Mohamed Said El-Shorbagy, Al-Sayed Mohamed Rashed, Ahmed Mohamed Alsawy. Effect of High Volume Hemodiafiltration on Secondary Hyperparathyroidism Among Hemodialysis Patients. Science Journal of Clinical Medicine.

Vol. 10, No. 3, 2021, pp. 78-84. doi: 10.11648/j.sjcm.20211003.12

Received: May 14, 2021; Accepted: July 12, 2021; Published: October 28, 2021

\begin{abstract}
Background: Despite increasing knowledge of the uraemic syndrome, both morbidity and mortality remain unacceptably high in patients with chronic kidney disease. Aim of the work: investigate the differences between conventional hemodialysis and hemodiafiltration in the context of chronic kidney disease metabolic bone disease findings serum calcium $(\mathrm{sCa})$, phosphate (sPO4) and intact parathyroid hormone (PTHint) concentrations. Patients and methods: This prospective cross over study was approved by Almaadi hospital committee and included 95 patients with CKD5 on regular hemodialysis for at least 6 months. Patients were divided into two groups: Group A: 60 patients scheduled 6 months conventional high flux (hf-HD) (Period1) followed by 6 months of post-dilutional-HDF (Period2). Group B: (controls) included 35 patients were kept on conventional hf-HD for 12 months. (Period3) for $1^{\text {st }} 6$ months and (Period4) for $2^{\text {nd }} 6$ months. The main variables evaluated at the start as well as at the end of each period were sCa, sPO4 and PTHint. Results: There was highly significant statistical decrease in Phosphorus level in period2 compared to other groups after $2^{\text {nd }}$ to $6^{\text {th }}$ month and average of overall $(\mathrm{p}<0.001)$. A significant statistical decrease was found in Parathormone level and CRP in period2 compared to other groups after 1 month to $6^{\text {th }}$ month and average of overall $(\mathrm{p}<0.05)$. There was significant statistical decrease in Albumin level in period 2 compared to other groups after $2^{\text {nd }}$ to $6^{\text {th }}$ month and average of overall $(\mathrm{p}<0.05)$. There was a significant statistical increase in $\mathrm{kt} / \mathrm{v}$ in period 2 compared to other groups after $1^{\text {st }}$ to $6^{\text {th }}$ month and average of overall $(\mathrm{p}<0.05)$. Conclusion: The switch over from conventional Hf-HD to Ol-HDF results in a significant reduction of both PO4 and PTH concentrations, no significant changes in $\mathrm{Ca}$ concentrations.
\end{abstract}

Keywords: High Volume Hemodiafiltration, Secondary Hyperparathyroidism, Hemodialysis

\section{Introduction}

Despite increasing knowledge of the uraemic syndrome, both morbidity and mortality remain unacceptably high in patients with chronic kidney disease (CKD) [1].

Secondary hyperparathyroidism which characterized by increased secretion of parathermone (PTH), is one of the major serious complications in patients with CKD on long-term hemodialysis (HD). Strict control of serum calcium and phosphate concentrations is very important to prevent secondary hyperparathyroidism in those patients [2].

Efficient removal of middle-molecular-weight (MMW) uremic toxins is expected to improve patient outcomes in dialysis [3].

Convective transport is the main driver for an enhanced clearance of such toxins. Consequently, hemodiafiltration (HDF), a dialysis procedure effectively combining diffusive and convective transport, has now become the standard dialysis technique in many countries [4].

MMW substances are not readily cleared by diffusion, which is the main elimination mechanism in low-flux HD [5].

European Dialysis Working Group (EUDIAL) defined 
hemodiafiltration as a blood purification therapy combining diffusive and convective solute transport such that the latter is achieved by an effective convection volume of at least $20 \%$ of the total blood volume processed. Convection volume is the sum of the substitution fluid volume and the volume of fluid removed during a session (i.e., the difference between the postdialysis and predialysis weights) [1].

In modern HDF, fluid balance is maintained by the infusion of 'online' prepared substitution fluid, which can be administered before the dialyser (pre-dilution), midway (mid-dilution) or after the dialyser (post-dilution) [6].

Since the vast majority of publications on HDF and clinical outcome concern online post-dilution HDF, this study will focus on this type of treatment.

This prospective switchover study investigated the differences between conventional hemodialysis and hemodiafiltration in the context of chronic kidney disease metabolic bone disease (CKDMBD) findings [serum calcium $(\mathrm{sCa})$, serum phosphate (sPO4) and intact parathyroid hormone (PTHint) concentrations].

\section{Patients and Methods}

This cross overstudy investigated the differences between conventional hemodialysis and hemodiafiltration in the context of CKDMBD findings stems from the fact that the same patients were examined by two different therapeutic modalities.

This study was approved by Almaadi hospital committeeand included 95 patients with CKD5 on regular hemodialysis (HD) in Almaadi Nephrology Unit for at least 6 months prior starting. They were selected after informing consent, full history, examination reviewing their medical records and fulfillment the study inclusion and exclusion criteria. They were divided into two groups: Group A included 60 patients scheduled 6 months conventional high flux hemodialysis (hf-HD) (Period1)) immediately followed by 6 months of post-dilutional-HDF (Period 2). Group B (controls) included 35 patients. They were kept on conventional hf-HD for 12 months. (Period3) for $1^{\text {st }} 6$ months and (Period4) for $2^{\text {nd }} 6$ months. The main variables evaluated at the start as well as at the end of each period were sCa, sPO4 and PTHint.

Variables in this study were evaluated both at the start and at the end of each period of observation. They included serum calcium ( $\mathrm{sCa} ; \mathrm{mg} / \mathrm{dL}$ ), serum phosphorus ( $\mathrm{sPO} 4$; $\mathrm{mg} / \mathrm{dL}$ ), serum intact parathyroid hormone (PTHint; $\mathrm{ng} / \mathrm{mL}$ ), total serum protein (sProt; g/dL), serum albumin ( $\mathrm{sAlb}$; $\mathrm{g} / \mathrm{dL})$, plasma sodium $(\mathrm{Na} ; \mathrm{mmol} / \mathrm{L})$, plasma potassium $(\mathrm{K}$; $\mathrm{mmol} / \mathrm{L})$, magnesium $(\mathrm{Mg} ; \mathrm{mg} / \mathrm{dL}), \mathrm{CBC}$, high sensitive $\mathrm{CRP}$, equilibrated $\mathrm{Kt} / \mathrm{V}(\mathrm{eKt} / \mathrm{V})$, body weight $(\mathrm{BW} ; \mathrm{kg})$, liver function tests, ECG, pre-dialysis systolic blood pressure (SBP; $\mathrm{mmHg}$ ) and diastolic blood pressure (DBP; $\mathrm{mmHg}$ ). All biochemical parameters were drawn before midweek dialysis session to be assayed by their standard methods.

1. Along the study, all patients (95 patients) used ultrapure dialysate as well as the same high flux dialyzer (High flux dialyzer, polysulfone F80 Fresenius Medical Care).

2. Treatment of mineral bone derangement was performed according to the American Kidney Disease Outcome Quality Initiative (K/DOQI 2013) clinical practice guidelines for bone metabolism and disease in chronic renal failure recommendations. In group $\mathrm{A}$, prescription and dosage changes of the phosphate binders done before the beginning ofperiod 1 and were kept constant during Period 2. While in group B, changes in the dosage and prescription of phosphate binders supplementation were allowed according to guidelines.

The study included patients above 18 years oldon regular HD for at least 6 months and with urinary output below 150 $\mathrm{mL} /$ interdialytic. While Patient swith active malignancy, chronic infections, decompensated liver cirrhosis, unstable within 3 months before study (myocardial infarction, congestive heart failure, stroke, recent surgery, or severe sepsis), patients who developed hyperphosphatemia were excluded, Vascular access dysfunction (blood flow rate $<300 \mathrm{~mL} / \mathrm{min}$ ) and urinary output more than $150 \mathrm{~mL} /$ interdialytic were excluded from the study.

\subsection{Dialysis Prescription}

Postdilution HDF was performed using the 5008 CorDiax HDF machine (Fresenius Medical Care, Bad Homburg, Germany). The dialysate solution is bicarbonate for all patients with sodium $\mathrm{Na}^{+} 140 \mathrm{mEq} / \mathrm{L}, \mathrm{K}^{+} 2 \mathrm{mEq} / \mathrm{L}, \mathrm{Ca}^{++}$ $1.75 \mathrm{mEq} / \mathrm{L}, \mathrm{Mg} 0.5 \mathrm{mEq} / \mathrm{L}, \mathrm{Cl}^{-} 109.5 \mathrm{mEq} / \mathrm{L}, \mathrm{HCO}_{3} 35 \mathrm{mEq} / \mathrm{L}$, $\mathrm{CHcooH} 3 \mathrm{mEq} / \mathrm{L} \&$ the blood pump was kept between 300 $400 \mathrm{~mL} / \mathrm{min}$ with dialysate flow $500 \mathrm{~mL} / \mathrm{min}$, and heparin sodium as anticoagulant were given $2500 \mathrm{IU}$ as a bolus on initiation of dialysis followed by $500-1000 \mathrm{IU} / \mathrm{Hr}$.

All procedures follow Al-Azhar University Ethical committee regulations, and patient consent was taken from all patients.

\subsection{Statistical Analysis}

Recorded data were analyzed using the statistical package for social sciences, version 20.0 (SPSS Inc., Chicago, Illinois, USA). Quantitative data were expressed as mean \pm standard deviation (SD). Qualitative data were expressed as frequency and percentage. The following tests were done: Independentsamples t-test of significance was used when comparing between two means. Chi-square $\left(\chi^{2}\right)$ test of significance was used in order to compare proportions between qualitative parameters. A one-way analysis of variance (ANOVA) when comparing between more than two means. Post Hoc test: Least Significant Difference (LSD) was used for multiple comparisons between different variables. The confidence interval was set to $95 \%$ and the margin of error accepted was set to $5 \%$. So, the p-value was considered significant as the following: Probability (P-value) P-value $<0.05$ was considered significant. P-value $<0.001$ was considered as highly significant. P-value $>0.05$ was considered insignificant. 


\section{Results}

The study shows no statistically significant differences between groups as regards demographic data.

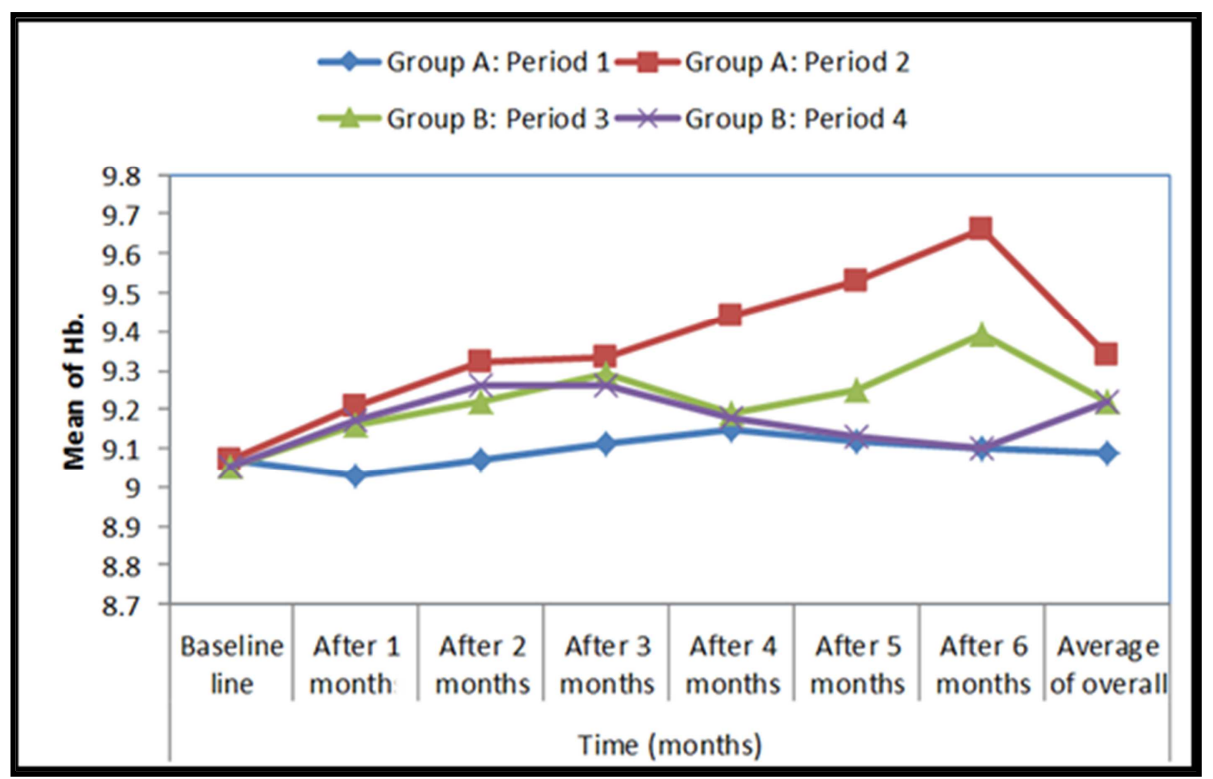

Figure 1. Comparison between groups according to $\mathrm{Hb}$.

This figure shows statistically significant difference between groups according to Hemoglobin $(\mathrm{Hb})$. From after 1 month to average of overall.

There is no significant statistical difference between the four groups as regard Hemoglobin level in the basal $(\mathrm{p}>0.05)$,
While there is significant statistical increase in Hemoglobin level in period 2 compared to other groupsafter the $1^{\text {st }}, 2^{\text {nd }}, 3^{\text {rd }}$, $4^{\text {th }}, 5^{\text {th }}$ month and average of overall $(\mathrm{p}<0.05)$ and highly significant statistical increase in Hemoglobin level in period 2 compared to other groups after the $6^{\text {th }}$ month $(\mathrm{p}<0.001)$.

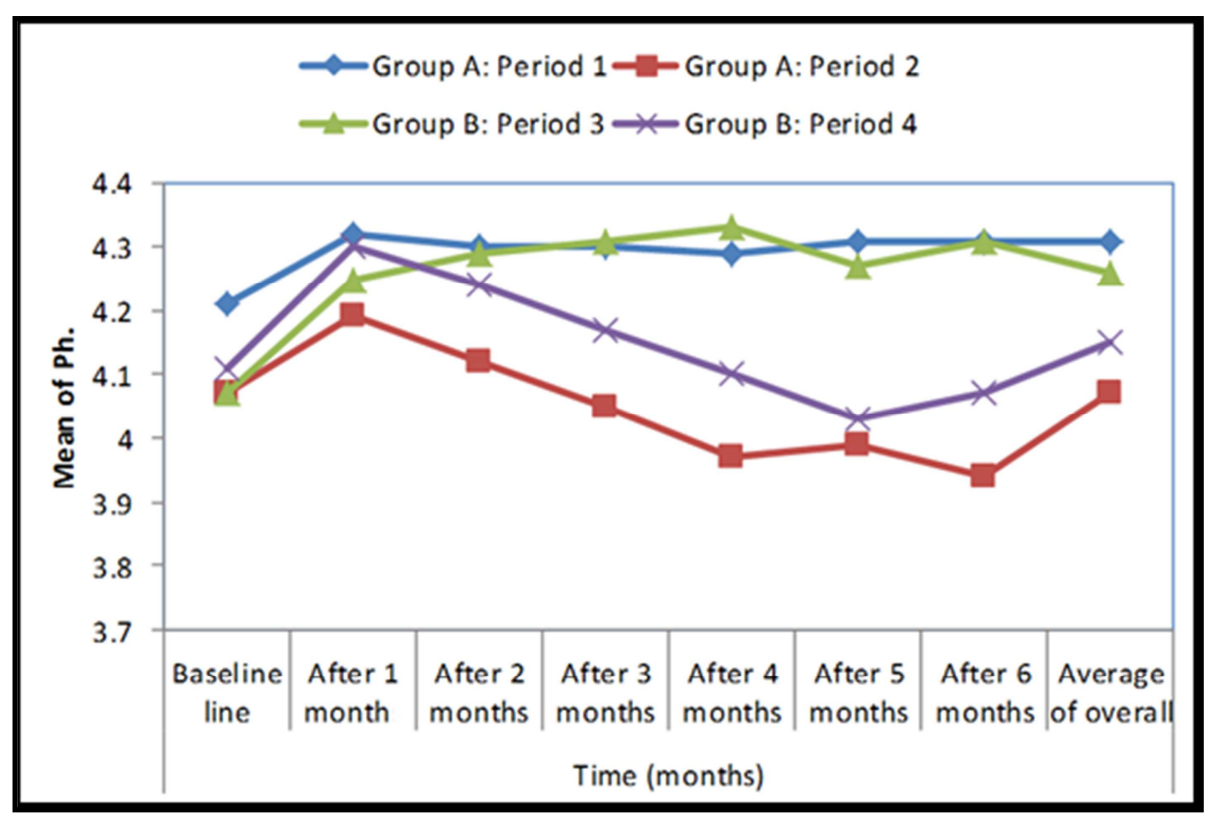

Figure 2. Comparison between groups according to Ph.

This figure shows statistically significant difference between groups according to Phosphorus (Ph) from after 1 month to Average of overall.

There is no significant statistical difference between the four groups as regard Phosphorus level in the basal ( $>0.05$ ), While there is significant statistical derease in Phosphoruslevel in period 2 compared to other groups after the $1^{\text {st }}$ month $(\mathrm{p}<0.05)$ and highly significant statistical decrease in Phosphorus level in period 2 compared to other groups after $2^{\text {nd }}, 3^{\text {rd }}, 4^{\text {th }}, 5^{\text {th }}, 6^{\text {th }}$ month and average of overall $(\mathrm{p}<0.001)$. 
Table 1. Comparison between groups according to Parathormone.

\begin{tabular}{|c|c|c|c|c|c|c|}
\hline \multirow{2}{*}{ PTH } & \multicolumn{2}{|l|}{ Group A } & \multicolumn{2}{|l|}{ Group B } & \multicolumn{2}{|c|}{ ANOVA } \\
\hline & Period $1(n=60)$ & Period $2(n=60)$ & Period $3(n=35)$ & Period $4(n=35)$ & $\mathbf{F}$ & p-value \\
\hline Baseline line & $392.65 \pm 176.69$ & $365.77 \pm 164.6$ & $370.04 \pm 166.52$ & $358.94 \pm 161.52$ & 0.109 & 0.954 \\
\hline After 1 months & $392.83 \pm 176.78$ & $367.43 \pm 165.34 a$ & $392.83 \pm 176.78 b$ & $381.05 \pm 171.47 \mathrm{~b}$ & 3.143 & $0.013 *$ \\
\hline After 2 months & $394.83 \pm 177.68$ & $365.57 \pm 164.51 \mathrm{a}$ & $394.83 \pm 177.68 b$ & $382.99 \pm 172.34 b$ & 3.426 & $0.012 *$ \\
\hline After 3 months & $395.52 \pm 177.98$ & $364.00 \pm 163.8 \mathrm{a}$ & $395.52 \pm 177.98 b$ & $383.65 \pm 172.64 b$ & 3.734 & $0.010 *$ \\
\hline After 4 months & $396.58 \pm 178.46$ & $364.71 \pm 164.12 \mathrm{a}$ & $396.58 \pm 178.46 b$ & $384.69 \pm 173.11 \mathrm{~b}$ & 3.585 & $0.009^{*}$ \\
\hline After 5 months & $372.83 \pm 253.28$ & $364.71 \pm 164.12 \mathrm{a}$ & $382.83 \pm 253.28 \mathrm{ab}$ & $371.95 \pm 145.68 b$ & 2.814 & $0.024 *$ \\
\hline After 6 months & $374.32 \pm 168.44$ & $360.15 \pm 131.3 \mathrm{a}$ & $374.32 \pm 168.44 b$ & $367.09 \pm 163.39 b$ & 3.304 & $0.012 *$ \\
\hline Average of overall & $415.65 \pm 187.04$ & $365.42 \pm 164.44 a$ & $412.42 \pm 185.59 \mathrm{~b}$ & $400.05 \pm 180.02 b$ & 3.172 & $0.014 *$ \\
\hline
\end{tabular}

$P$ value at 0.05 was considered significant, while at 0.01 and 0.001 are highly significant.

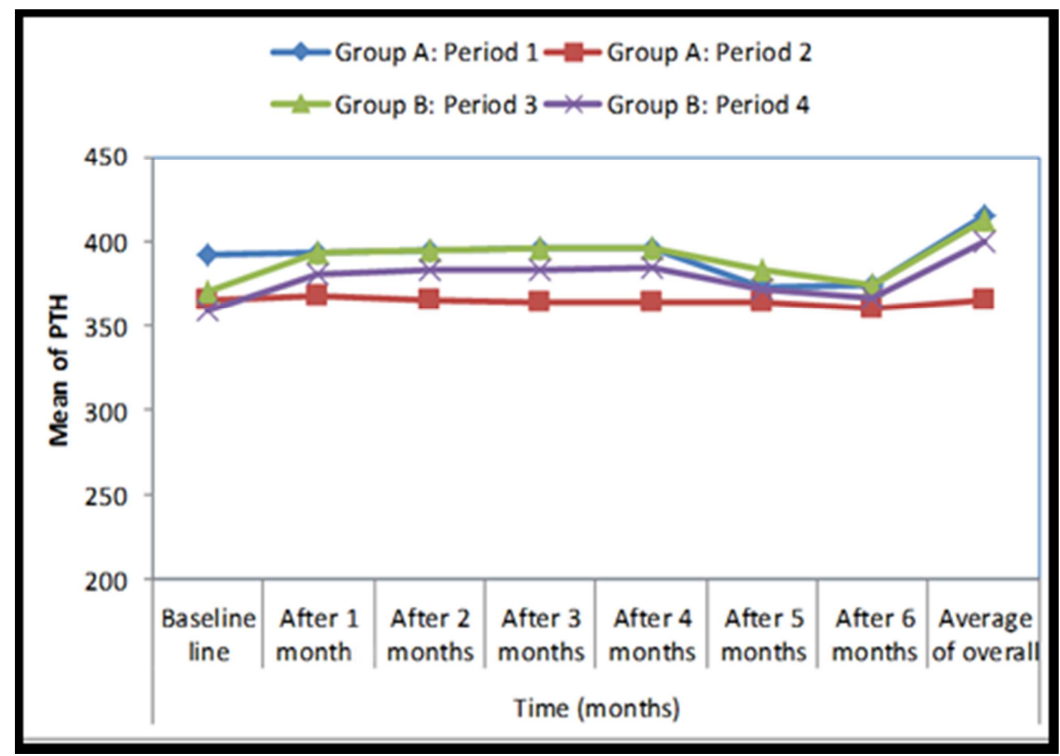

Figure 3. Comparison between groups according to PTH.

As shown in table 1 and figure 3, there was a statistically significant difference between groups according to Parathormone (PTH) from after 1 month to Average of overall.

There is no significant statistical difference between the four groups as regard Parathormone level in the basal $(p>0.05)$, While there is significant statistical derease in Parathormone level in period 2 compared to other groups after 1 month to $6^{\text {th }}$ month andaverage of overall $(\mathrm{p}<0.05)$.

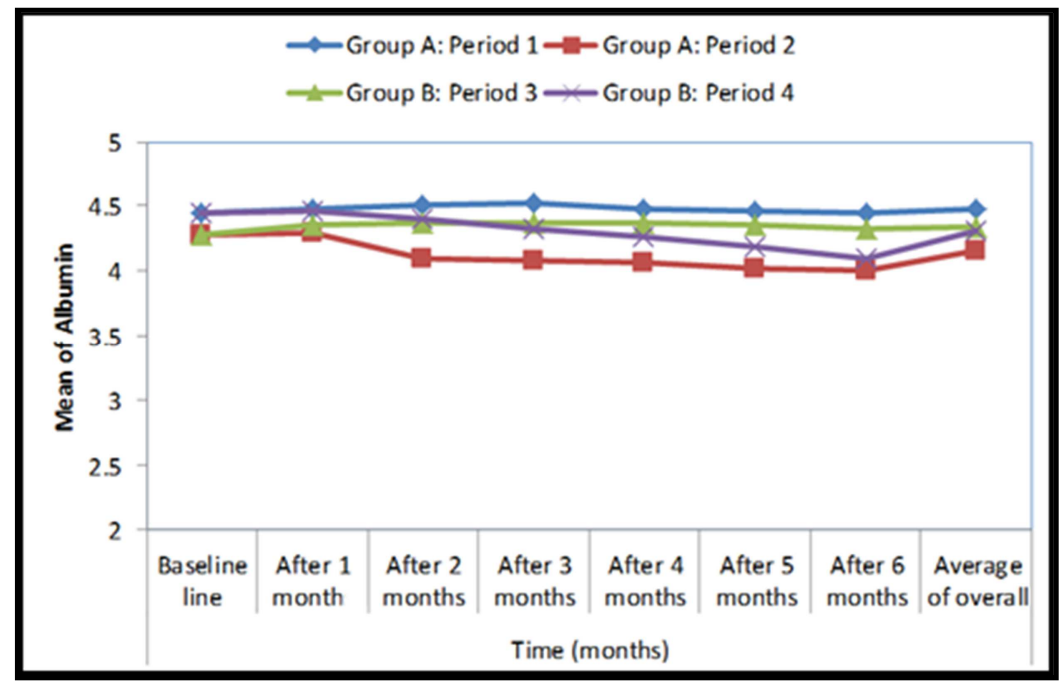

Figure 4. Comparison between groups according to Albumin.

This figure shows statistically significant difference between period 2 and overall of the periods according to 
albumin from after 2 months to Average of overall.

There is no significant statistical difference between the four groups as regard Albumin level in the basal and after $1^{\text {st }}$ month ( $\mathrm{p}>0.05)$, While there is significant statistical derease in Albumin level in period 2 compared to other groups after $2^{\text {nd }}$ to $6^{\text {th }}$ month and average of overall $(\mathrm{p}<0.05)$.

Table 2. Comparison between groups according to $C$ reactive Protein.

\begin{tabular}{|c|c|c|c|c|c|c|}
\hline \multirow{2}{*}{ CRP } & \multicolumn{2}{|l|}{ Group A } & \multicolumn{2}{|l|}{ Group B } & \multicolumn{2}{|c|}{ ANOVA } \\
\hline & Period $1(n=60)$ & Period $2(n=60)$ & Period $3(n=35)$ & Period $4(n=35)$ & $\mathbf{F}$ & p-value \\
\hline Baseline line & $10.4 \pm 4.37$ & $10.4 \pm 4.37$ & $9.8 \pm 4.12$ & $9.8 \pm 4.12$ & 0.188 & 0.905 \\
\hline After 1 months & $10.47 \pm 4.4$ & $9.11 \pm 3.83 \mathrm{a}$ & $10.6 \pm 4.45 b$ & $10.51 \pm 4.42 b$ & 2.801 & $0.042 *$ \\
\hline After 2 months & $10.43 \pm 4.38$ & $9.07 \pm 3.81 \mathrm{a}$ & $10.43 \pm 4.38 b$ & $10.8 \pm 4.54 b$ & 2.320 & $0.044 *$ \\
\hline After 3 months & $10.52 \pm 4.42$ & $9.15 \pm 3.85 \mathrm{a}$ & $10.29 \pm 4.32 b$ & $10.29 \pm 4.32 b$ & 4.242 & $0.008 *$ \\
\hline After 4 months & $10.41 \pm 4.37$ & $9.06 \pm 3.80 \mathrm{a}$ & $10.66 \pm 4.48 b$ & $10.23 \pm 4.3 b$ & 3.711 & $0.033 *$ \\
\hline After 5 months & $10.45 \pm 5.06$ & $8.74 \pm 4.40 \mathrm{a}$ & $10.26 \pm 4.31 b$ & $10.14 \pm 4.26 b$ & 2.779 & $0.014 *$ \\
\hline Average of overall & $10.66 \pm 4.48$ & $9.27 \pm 3.90 \mathrm{a}$ & $10.34 \pm 4.34 b$ & $10.23 \pm 4.3 b$ & 3.025 & $0.036^{*}$ \\
\hline
\end{tabular}

$P$ value at 0.05 was considered significant, while at 0.01 and 0.001 are highly significant.

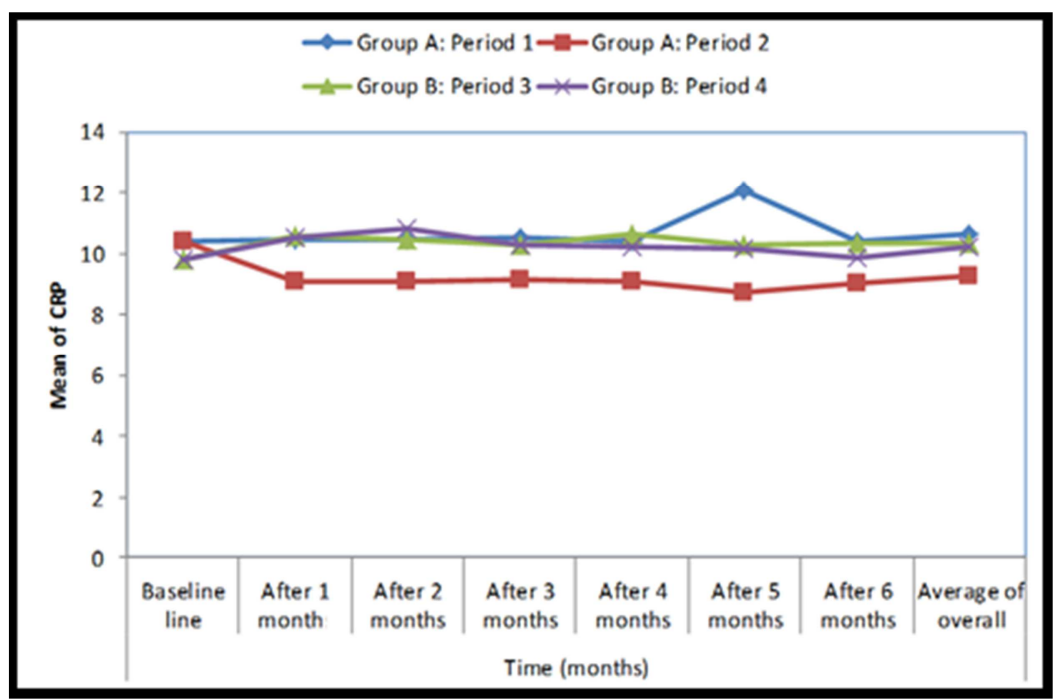

Figure 5. Comparison between groups according to CRP.

This figure shows statistically significant difference between period 2 and overall of the periods according to CRP from after 1 months to Average of overall.

There is no significant statistical difference between the four groups as regard CRP in the basal $(p>0.05)$, While there is significant statistical derease in CRP in period 2 compared to other groups after $1^{\text {st }}$ to $6^{\text {th }}$ month and average of overall $(\mathrm{p}<0.05)$.

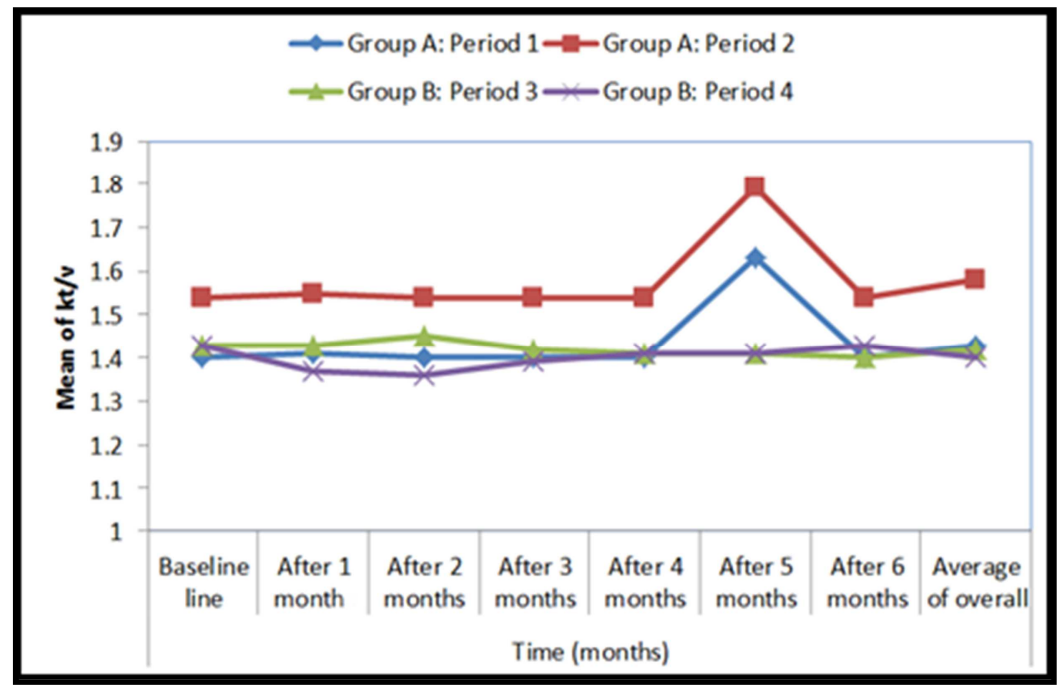

Figure 6. Comparison between groups according to kt/v. 
This figure shows statistically significant difference between groups according to $\mathrm{kt} / \mathrm{v}$ from after 1 month to Average of overall.

There is no significant statistical difference between the four groups as regard $\mathrm{kt} / \mathrm{v}$ in the basal $(\mathrm{p}>0.05)$, While there is significant statistical inrease in $\mathrm{kt} / \mathrm{v}$ in period 2 compared to other groups after $1^{\text {st }}$ to $6^{\text {th }}$ month and average of overall $(\mathrm{p}<0.05)$.

\section{Discussion}

Hemodiafiltration (HDF) is a newer technique of dialysis that achieves clearance of middle and large molecular weight solutes unlike conventional hemodialysis (HD). HD is based on the diffusive transport of solutes across a semi permeable membrane and is effective in removing small solutes only, whereas HDF also involves the infusion of sterile, pyrogenfree fluid either pre- or post-filter and thereby allows clearance by convection as well as diffusion [7].

Our study was conducted on 95 chronic hemodialysis patients on regular hemodialysis (HD). They were divided into four groups: Group A included 60 patients scheduled 6 months conventional high flux (hf-HD) (Period1) immediately followed by 6 months of post-dilutional-HDF (Period 2). Group B (controls) included 35 patients. They were kept on conventionalhf-HDfor 12 months. (Period3) for $1^{\text {st }} 6$ months and (Period4) for $2^{\text {nd }} 6$ months.

In group A: 30 of them were females $(50 \%), 30$ of them were males $(50 \%)$.

Anemia is a major comorbidity of patients with end-stage renal disease and poses an enormous economic burden to health-care systems. High dose erythropoiesis-stimulating agents (ESAs) have been associated with unfavorable clinical outcomes [8].

In our study There is no significant statistical difference between the four groups as regard Hemoglobin level in the basal ( $p>0.05)$, While there is significant statistical increase in Hemoglobin level in period 2 compared to other groups after the $1^{\text {st }}, 2^{\text {nd }}, 3^{\text {rd }}, 4^{\text {th }}, 5^{\text {th }}$ month and average of overall $(p<0.05)$ and highly significant statistical increase in Hemoglobin level in period 2 compared to other groups after the $6^{\text {th }}$ month $(\mathrm{p}<0.001)$, which agree with the study done by $[9,2]$; but this result disagree with the study done by $[10,11]$ which showed no change in Hemoglobin level.

Phosphorus is found in plasma in a variety of compounds, such as pyrophosphates, decametaphosphates or phosphates bound to proteins. These forms of phosphorus have higher molecular weights and lower diffusion rates, so that their removal can be only improved by adding convective clearance [12].

There is no significant statistical difference between the four groups as regard Phosphorus level in the basal $(p>0.05)$, While there is significant statistical derease in Phosphorus level in period 2 compared to other groups after the $1^{\text {st }}$ month $(\mathrm{p}<0.05)$ and highly significant statistical decrease in Phosphorus level in period 2 compared to other groups after $2^{\text {nd }}, 3^{\text {rd }}, 4^{\text {th }}, 5^{\text {th }}, 6^{\text {th }}$ month and average of overall $(\mathrm{p}<0.001)$; which agree with the study done by [10]. but this result disagree with the study done by [13] in which Phosphate levels were higher in patients who were on HDF compared with high-flux HD.

High serum PTH levels in ESKD have been related to a poor clinical outcome [14].

There is no significant statistical difference between the four groups as regard Parathormone level in the basal $(\mathrm{p}>0.05)$, While there is significant statistical derease in Parathormone level in period 2 compared to other groups after 1 month to $6^{\text {th }}$ month and average of overall $(\mathrm{p}<0.05)$; which agree with the study done by [10]; but this result disagree with the study done by [11] In which there are any changes in serum levels of PTH.

Albumin loss during online HDF treatment is dependent both on the filtration volume and the type of membrane was recently confirmed in a controlled study, which however only assessed albumin loss during the first hour of treatment [15].

The clinical relevance of some extra albumin loss during post dilution online HDF, however, is uncertain. [16] did not observe a relation between albumin lossand nutritional parameters.

There is no significant statistical difference between the four groups as regard Albumin level in the basal and after $1^{\text {st }}$ month ( $p>0.05)$, While there is significant statistical derease in Albumin level in period 2 compared to other groups after $2^{\text {nd }}$ to $6^{\text {th }}$ month and average of overall $(\mathrm{p}<0.05)$; which agree with the study done by [11] but this result disagree with the study done by [13] inwhich Mean serum albumin was not significantly different between patients who were treated predominantly with HDFor high-flux HD.

Systemic inflammation is commonly observed in patients with chronic kidney disease and has been shown to have a role in the development and progression of cardiovascular disease (CVD) and to predict mortality in end-stage kidney disease [17].

Online hemodiafiltration (olHDF) may decrease inflammatory activity through enhanced clearance of middle molecules by convection; on the other hand, the infusion of large amounts of substitution fluid may induce inflammatory activity when water is contaminated. However, the potential risk of contamination is very low as we and others previously showed by analyzing a large amount of samples of dialysis fluids [18].

There is no significant statistical difference between the four groups as regard CRP in the basal $(\mathrm{p}>0.05)$, While there is significant statistical derease in CRP in period 2 compared to other groups after $1^{\text {st }}$ to $6^{\text {th }}$ month and average of overall $(p<0.05)$. This result agrees with the study done by [19] and [9] and this result disagrees with the study done by [20] and [21], in which there was no difference in the C-reactive protein ratios comparing HD vs. olHDF treatments.

There is no significant statistical difference between the four groups as regard $k t / v$ in the basal $(p>0.05)$, While there is significant statistical inrease in $\mathrm{kt} / \mathrm{v}$ in period 2 compared 
to other groups after $1^{\text {st }}$ to $6^{\text {th }}$ month and average of overall $(p<0.05)$. This result agrees with the study done by [22] and this result disagrees with the study done by [10], in which there are similar kt/v in both groups Online Hemodiafiltration and High-Flux Hemodialysis.

\section{Conclusion}

In conclusion, in this study, the switch over from conventional Hf-HD to Ol-HDF results in a significant reduction of both $\mathrm{PO} 4$ and $\mathrm{PTH}$ concentrations, no significant changes in $\mathrm{Ca}$ concentrations. This supports the idea that Ol-HDF could be of help in controlling the uraemic mineral metabolism derangement in dialysis patients. Online hemodiafiltration (HDF) may decrease inflammatory activity. Hemoglobin level and $\mathrm{kt} / \mathrm{v}$ were higher in patients whowere treated with Ol-HDF. Loss of albumin was higher in the OlHDF group.

\section{References}

[1] Tattersall JE, Ward RA (2013). Online haemodiafiltration: definition, dose quantification and safety revisited. Nephrol Dial Transplant; 28: 542-50.

[2] Locatelli F, Altieri P, Andrulli S, et al. (2010): Hemofiltration and hemodiafiltration reduce intradialytic hypotension in ESRD. J Am SocNephrol.; 21: 1798-1807.

[3] Lornoy W, Becaus I, Billiouw JM, et al. (2000): On-line haemodiafiltration: remarkable removal of $\beta 2$-microglobulin. Long-term clinical observations. Nephrol Dial Transplant; 15 (Suppl. 1): 49-54.

[4] Marcelli D, Scholz C, Ponce P, et al. (2015): High-Volume PostdilutionHemodiafiltration Is a Feasible Option in Routine Clinical Practice. Artificial Organs, 39 (2): 142-149.

[5] Ledebo I, Blankestijn PJ (2010). Haemodiafiltration-optimal efficiency and safety. NDT Plus; 3: 8-16.

[6] Mostovaya I M, Muriel P. C, Grooteman, et al. (2015): High convection volume in online post-dilution haemodiafiltration: relevance, safety and costs Clinical Kidney Journal. 8, (4): 368-373.

[7] Leurs P, Lindholm B, Stenvinkel P (2013). Effects of hemodiafiltration on uremic inflammation. Blood Purif.; 35 Suppl 1: 11-7. doi: 10.1159/000346359.

[8] Luciano A. Pedrini, Adam M. Zawada, Anke C. Winter, et al. (2019): Effects of high-volume online mixedhemodiafiltration on anemia management in dialysis patients. https://doi.org/ 10.1371/journal.pone.0212795.

[9] Maduell F, Javier Varas, Rosa Ramos, et al. (2017): Hemodiafiltration Reduces All-Cause and Cardiovascular Mortality in Incident Hemodialysis Patients: A PropensityMatched Cohort Study. Am J Nephrol; 46: 288-297.
[10] EzioMovilli, CorradoCamerini, Paola Gaggia, etal. (2011): Effect of post-dilutional on-line haemodiafiltration on serum calcium phosphate and parathyroid hormone concentrations in uraemic patients. Nephrol Dial Transplant 26: 4032-4037.

[11] Guillaume Jean, Jean-Marc Hurot, PatrikDeleaval, et al. (2015): Online-haemodiafiltration vs. conventional haemodialysis: a cross-over study. Jean, et al. BMC Nephrology 16: 70.

[12] Davenport A, Gardner C, Delaney M; Pan Thames Renal Audit Group (2010): The effect of dialysis modality on phosphate control: haemo-dialysis compared to haemodiafiltration. The Pan Thames Renal Audit. Nephrol Dial Transplant; 25: 897-901.

[13] Vilar E, Fry AC, Wellsted D, et al. (2009): Long-term outcomes in online hemodiafiltration and high-flux hemodialysis: a comparative analysis. Clin J Am SocNephrol; 4: 1944-1953.

[14] Kovesdy CP, Ahmadzadeh S, Anderson JE, et al. (2008): Secondary hyperparathyroidism is associated with higher mortality in men with moderate to severe chronic kidney disease. Kidney Int; 73 (11): 1296-302.

[15] Vega A, Quiroga B, Abad S, et al. (2015): Albumin leakage in online hemodiafiltration, more convective transport, more losses? TherApher Dial. 19 (3): 267-71.

[16] Fournier A, Birmele B, Francois M, et al. (2015): Factors associated with albumin lossin post-dilution hemodiafiltration and nutritional consequences. Int J Artif Organs. 38 (2): 76 82.

[17] Bazeley J, Bieber B, Li Y, et al. (2011): C-reactive protein and prediction of 1-year mortality in prevalent hemodialysis patients. Clin J Am SocNephrol; 6: 2452-2461.

[18] Penne EL, Visser L, van den Dorpel MA, et al. (2009): Microbiological quality and quality control of purified water and ultrapure dialysis fluids for online hemodiafiltration in routine clinical practice. Kidney Int 76: 665-672.

[19] Claire H. den Hoedt, Michiel L. Bots, Muriel P. C. Grooteman (2014). Online hemodiafiltration reduces systemic inflammation compared to low-flux hemodialysis.

[20] Ping Jia, Wei Jin, JieTeng, et al. (2016): Acute Effects of HemodiafiltrationVersus Conventional Hemodialysis on Endothelial Function and Inflammation, A Randomized Crossover Study. Medicine_ Volume 95, Number 16.

[21] Grit Waitz, Jürgen Bock, Peter Ahrenholz, et al. (2018): Albumin/ C-reactive protein ratio in the treatment of patients with chronic kidney disease - high flux hemodialysis vs. online hemodiafiltration. https://doi.org/10.1093/ndt/gfy104.FP463.

[22] Francesco Locatelli, Angelo Karaboyas, Ronald L. Pisoni (2018). Mortality risk in patients on hemodiafiltration versus hemodialysis: a 'real-world' comparison from the DOPPS. Nephrol Dial Transplant 33: 683-689. 